\title{
Effects of Landscape Positions and Landscape Types on Soil Properties and Chlorophyll Content of Citrus in a Sloping Orchard in the Three Gorges Reservoir Area, China
}

\author{
Siyue Sun ${ }^{1}$, Guolin Zhang ${ }^{2}$, Tieguang $\mathrm{He}^{3, *}$, Shufang Song ${ }^{4}$ and Xingbiao Chu ${ }^{1, *}$ \\ 1 College of the Arts, Guangxi University, Nanning 530004, China; 2024393014@st.gxu.edu.cn \\ 2 College of Architecture and Landscape, Peking University, Beijing 100080, China; gl.zhang@pku.edu.cn \\ 3 Agricultural Resources and Environment Research Institute, Guangxi Academy of Agricultural Sciences, \\ Nanning 530007, China \\ 4 School of Information and Statistics, Guangxi University of Finance and Economics, Nanning 530003, China; \\ ssffsong@gxufe.edu.cn \\ * Correspondence: htg118@gxaas.net (T.H.); 20130112@gxu.edu.cn (X.C.)
}

\section{check for} updates

Citation: Sun, S.; Zhang, G.; He, T.; Song, S.; Chu, X. Effects of Landscape Positions and Landscape Types on Soil Properties and Chlorophyll Content of Citrus in a Sloping Orchard in the Three Gorges Reservoir Area, China. Sustainability 2021, 13, 4288. https://doi.org/ $10.3390 /$ su13084288

Academic Editors: Bharat Sharma Acharya and Rajan Ghimire

Received: 11 March 2021

Accepted: 6 April 2021

Published: 12 April 2021

Publisher's Note: MDPI stays neutral with regard to jurisdictional claims in published maps and institutional affiliations.

Copyright: (c) 2021 by the authors. Licensee MDPI, Basel, Switzerland. This article is an open access article distributed under the terms and conditions of the Creative Commons Attribution (CC BY) license (https:/ / creativecommons.org/licenses/by/ $4.0 /)$.

\begin{abstract}
In recent years, soil degradation and decreasing orchard productivity in the sloping orchards of the Three Gorges Reservoir Area of China have received considerable attention both inside and outside the country. More studies pay attention to the effects of topography on soil property changes, but less research is conducted from the landscape. Therefore, understanding the effects of landscape positions and landscape types on soil properties and chlorophyll content of citrus in a sloping orchard is of great significance in this area. Our results showed that landscape positions and types had a significant effect on the soil properties and chlorophyll content of citrus. The lowest soil nutrient content was detected in the upper slope position and sloping land, while the highest exists at the footslope and terraces. The chlorophyll content of citrus in the middle and upper landscape position was significantly higher than the footslope. The redundancy analysis showed that the first two ordination axes together accounted for $81.32 \%$ of the total variation, which could be explained by the changes of soil total nitrogen, total phosphorus, total potassium, available nitrogen, available potassium, organic matter, $\mathrm{pH}$, and chlorophyll content of the citrus. Overall, this study indicates the significant influence of landscape positions and types on soil properties and chlorophyll content of citrus. Further, this study provides a reference for the determination of targeted land management measures and orchard landscape design so that the soil quality and orchard yield can be improved, and finally, the sustainable development of agriculture and ecology can be realized.
\end{abstract}

Keywords: agriculture landscape; chlorophyll content of citrus; landscape position; soil properties; terraces

\section{Introduction}

The Three Gorges Reservoir Area of China is one of the most suitable ecological areas for the growth of citrus. The citrus industry has achieved a dominant position in the development of mountainous agriculture and rural economy in this area [1]. Currently, the mountainous agriculture in this area is transforming from conventional farming systems to suburban modern agriculture and leisure and sightseeing agriculture, and the ecosystem service function contained in it has begun to attract attention [2]. Citruses are planted on the sloping land along the Yangtze River and its tributaries because of cultivated land tension in this area. For a long time, orchard managers have been ignoring soil conservation practices, and indiscriminately using large amounts of fertilizers without considering soil differences, which has led to serious problems such as chemical fertilizer pollution, soil degradation, and orchard production reduction, and brought great harm to agricultural production and ecological environment in the area [3-5]. 
Soil properties, the most important factor determining soil quality, not only affect crop output, but also have a significant impact on the cultivated land use and soil environmental protection [6-8]. Several previous studies have confirmed the effects of terrain, land use, hedgerows, and other environmental factors and management measures on soil quality in the Three Gorges Reservoir Region [9]. Teng Mingjun et al. [10] found that topographical factors are the main factors that cause the spatial heterogeneity of soil organic carbon in the reservoir area. Shen Zhenyao et al. [11] found that load intensities of nitrogen, phosphorus, and other non-point source pollutants were significantly different in soils with different land-use patterns. Xu Feng et al. [12] showed that slope ecological engineering with contour hedgerows could effectively control slope erosion and nutrient loss.

However, in the Three Gorges Reservoir Region, a fragile ecoregion and a developing leisure and sightseeing agricultural area, there are a few studies on the change of soil properties caused by the landscape. Each soil property has a respective spatial distribution in the landscape. The landscape position affects the process of soil formation, so it is considered to be one of the key factors affecting the changes of soil properties [13,14]. Simultaneously, landscape types also cause changes in soil spatial distribution. Arnaz's [15] study found that when sloping land transformed into terraced land, the slope's length and angle decreased significantly, resulting in a decrease in soil erosion and sediment yield. Although soil properties are influenced by many factors, such as climate, parent material, and biological factors, the influence of landscape types and landscape positions cannot be ignored on the regional scale [16]. Therefore, in this area, soil-landscape analysis is crucial to understand the spatial variation law of soil properties for determining targeted land management interventions to improve soil quality, form a charming farmland landscape, and achieve sustainable agricultural development [17].

Additionally, more researchers believe that it is best to combine soil analysis with leaf analysis to comprehensively diagnose the soil quality and citrus nutritional status to guide rational fertilization, improve citrus quality, and increase citrus yield. Mohesh et al. [18,19] Showed that the chlorophyll content of plant leaves determines the photosynthetic capacity and nutritional status of leaves, which can be used as an indicator of plant health. Haboudane et al. [20-22] point out that chlorophyll content in crops plays a key in precision agriculture because it is related to nitrogen concentration in the leaf of a crop. It reflects how the crop responds to nitrogen application, as well as being an important indicator of photosynthetic activity, which determines crop yield. Therefore, it is necessary to assess the comprehensive impact of environmental factors on soil and citrus trees in combination with the changes of the chlorophyll content of citrus (CCC).

The purposes of this study are: (1) to evaluate the effects of landscape position and landscape type on soil properties, including soil total nitrogen, total phosphorus, total potassium, available potassium, available nitrogen, available phosphorus, soil organic matter, and $\mathrm{pH}$; and (2) to evaluate the effects of landscape position and landscape type on CCC. This information provides a reference for knowing how the local ecosystem works and assessing the impact of future landscape changes. It is not only helpful for the determination of targeted orchard land management measures and the formation of a good agricultural landscape but also related to the ecological environment safety and sustainable development of the agricultural economy in the middle and upper reaches of the Yangtze River.

\section{Materials and Methods}

\subsection{Study Area}

The study area is in the citrus orchard in Guo Jiagou, Fengjie County, Chongqing, China $\left(31^{\circ} 06^{\prime} \mathrm{N}, 109^{\circ} 27^{\prime} \mathrm{E}\right.$, Figure 1$)$. Fengiie County, with an altitude ranging from 86 to $2123 \mathrm{~m}$ above sea level, is a mountainous landform in the eastern Sichuan Basin and the mountainous area accounts for $88.3 \%$ of the total (Figure 1D). The Yangtze River runs through the middle of Fengjie County, stretching $41.5 \mathrm{~km}$, with Mei Xi River, Da Xi River, Shi Sun River, Cao Tang River, Zhu Yi River, and other rivers. Fengjie County is 
a typical subtropical monsoon climate with four distinct seasons, abundant rainfall, and long sunshine hours. Due to the influence of topography and landform, the vertical change of climate is more obvious and forms a typical three-dimensional climate. The frost-free period is about 287 days; average annual temperature is $16.3^{\circ}$, average precipitation is about $1150 \mathrm{~mm}$, and average sunshine duration is $1639 \mathrm{~h}$.

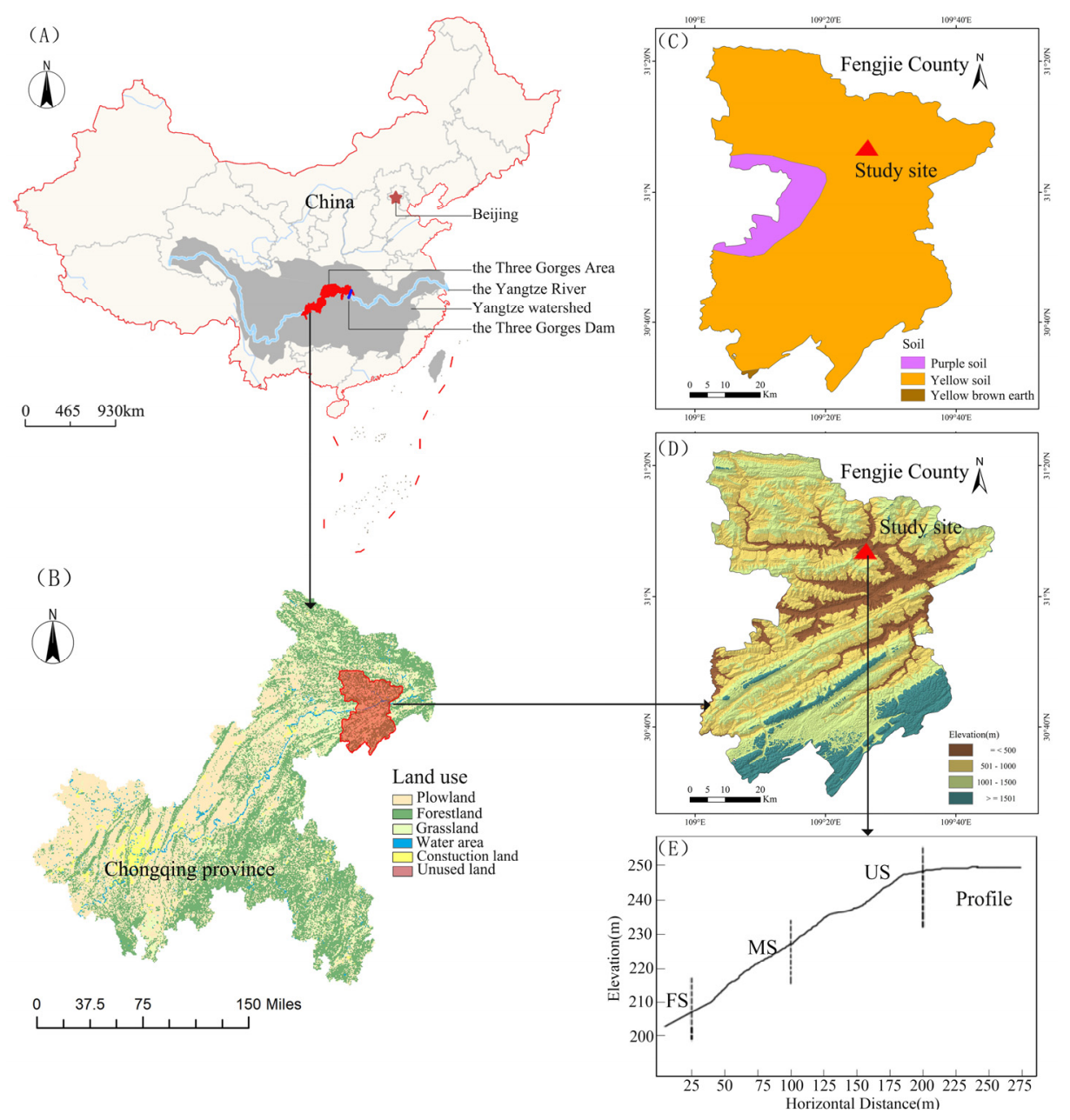

Figure 1. (A) The geographical location of the Yangtze watershed in China. (B) The land use map of Chongqing province. (C) The soil distribution map of study area. (D) The geographical structure of study area. (E) The geomorphic profile of the study site.

Fengjie County is located in the core area of the citrus industrial belt in the middle and upper reaches of the Yangtze River. As of March 2021, the citrus planting area of Fengjie County has reached $246.7 \mathrm{~km}^{2}$, the output has reached 370,000 tons, and the comprehensive output value has exceeded 3.5 billion yuan, accounting for about $20 \%$ of the total agricultural output value. This has led to the income increase of 0.3 million people in 24 towns and 70,000 households, and the employed population accounts for $28.4 \%$ of the total population of Fengiie County. Citrus trees in the study area were planted in 1980; the variety is Feng Yuan 72-1, the row spacing of citrus plants is $4 \mathrm{~m} \times 4 \mathrm{~m}$, and the height of the canopy is 3-4 m. In 1990, part of the sloping land was changed to contour terraces, and the slope of the surface was 5 degrees, showing a trend of high inside and low outside. At present, in the study area the most agricultural landscape is sloping landscape, with a few being terraced landscape.

The soil distribution in Fengjie County is shown in Figure 1C and Table 1. The soil in the study area is mainly yellow soil, and the profile configuration is A-B-C type. The thickness of the soil layer is generally more than $60 \mathrm{~cm}$, and the color is yellow or brownish 
yellow. The content of silt is $36.9-44.38 \%$, clay is $30 \%$, and the texture is loamy clay. This kind of soil has a deep soil layer, heavy texture, total porosity of about $59 \%$, and strong water and fertility conservation.

Table 1. Information about the geological structure, soils, and land use of the analyzed catchment.

\begin{tabular}{cccc}
\hline Item & Classification & Area $\mathbf{( k m}^{\mathbf{2}} \mathbf{)}$ & Proportion $\mathbf{( \% )}$ \\
\hline \multirow{3}{*}{ Soil } & Purple soil & 297.3 & 7.3 \\
& Yellow soil & 3796.7 & 92.7 \\
& Yellow brown earth & 5.1 & 0.1 \\
\hline \multirow{3}{*}{ Geography } & $\leq 500 \mathrm{~m}$ & 636 & 14.1 \\
& $501-1000 \mathrm{~m}$ & 1820.1 & 40.3 \\
& $1001-1500 \mathrm{~m}$ & 1520.2 & 33.7 \\
& $\geq 1501 \mathrm{~m}$ & 537.3 & 11.9 \\
\hline \multirow{3}{*}{ Land use } & Plowland & 37,504 & 45.5 \\
& Forestland & 33,575 & 40.7 \\
& Grassland & 7608 & 9.2 \\
& Water area & 333 & 0.4 \\
& Construction land & 2399 & 2.9 \\
& Unused land & 12 & 0.01 \\
\hline
\end{tabular}

The data of soil and topography is from Fengiie County. The data of land use is from Chongqing.

\subsection{Experimental Design}

This study was conducted in August 2020 in the citrus orchard operated by Fengjie County Agriculture Development Ecology Co., Ltd., Chongqing, China. Two adjacent slopes with different landscape types were chosen to explore the effects of landscape positions and landscape types on soil properties and CCC in the study area. One of the slopes is a sloping landscape, the other is a contour terrace in the upper slope position, and the middle slope and footslope positions are sloping landscapes. Refer to the research methods of Brubaker et al. to divide slope landscape position [23]. The research is divided into three parts (Figure 1E): the upper landscape position (US), the middle landscape position (MS), and the foot of slope (FS). Landscape types are divided into sloping landscape and terraced landscape. A total of representative 24 plots $(4 \mathrm{~m} \times 4 \mathrm{~m})$ were selected based on landscape positions and landscape types: 8 in the US, 8 in the MS, and 8 in the FS. The landscape position, landscape type, and geographical location of each sampling plot were recorded, and slope gradient, slope aspect, and elevation were measured. The basic information of sample plots in different landscape positions is shown in Table 2.

Table 2. The basic information of sample plots in different landscape positions.

\begin{tabular}{ccccccc}
\hline $\begin{array}{c}\text { Landscape } \\
\text { Position }\end{array}$ & $\begin{array}{c}\text { Geographic } \\
\text { Position }\end{array}$ & Elevation (m) & Slope $\left(^{\circ}\right)$ & Slope Aspect $\left(^{\circ}\right)$ & $\begin{array}{c}\text { Number of } \\
\text { Plots }\end{array}$ & $\begin{array}{c}\text { Dominant Landscape } \\
\text { Position }\end{array}$ \\
\hline FS & $\begin{array}{c}31^{\circ} 6^{\prime} 55^{\prime \prime} \mathrm{N} \\
109^{\circ} 27^{\prime} 24^{\prime \prime} \mathrm{E} \\
31^{\circ} 6^{\prime} 52^{\prime \prime} \mathrm{N}\end{array}$ & 210 & $19-23$ & $302-355$ & 8 & slopes \\
& $\begin{array}{c}109^{\circ} 27^{\prime} 25^{\prime \prime} \mathrm{E} \\
31^{\circ} 6^{\prime} 49^{\prime \prime} \mathrm{N}\end{array}$ & 225 & $30-36$ & $78-355$ & 8 & slopes \\
$109^{\circ} 27^{\prime} 26^{\prime \prime} \mathrm{E}$ & 240 & $5-21$ & $347-352$ & 8 & terraces, slopes \\
MS & & & & & & \\
\end{tabular}

FS = the footslope position, MS = the middle slope position, US = the upper slope position.

\subsection{Soil Sampling and Chlorophyll Content of Citrus}

In August 2020, soil samples were collected for 24 plots by the diagonal sampling method. After clearing the top litter, three individual soil samples $(0-15 \mathrm{~cm}$, one from the center of the field, two from diagonal corners) were taken from a plot and mixed to get 1 sample. The samples were air-dried and sent to the Guangxi Academy of Agricultural 
Sciences to determine the contents of soil total nitrogen, total phosphorus, total potassium, available nitrogen, available phosphorus, available potassium, organic matter, and $\mathrm{pH}$.

The CCC, expressed as a chlorophyll content index (CCI) was measured using the CCM-200 plus Chlorophyll Content Meter (OPTI-SCIENCES, Hudson, NH, USA) between 8:00 and 10:00 a.m. on 28 and 29 August 2020 (sunny cloudless). The measurement method was to select well-developed and fully developed leaves from the upper, middle, and lower locations of the south of a citrus tree. After measuring each leaf four times, the mean value of chlorophyll content in the upper, middle, and lower tree locations was taken.

\subsection{Data Analysis}

\subsubsection{Statistics Analysis}

Statistical analyses were conducted using Excel 2016 (Microsoft, Redmond, WA, USA) and SPSS 24.0 (IBM, Armonk, NY, USA). A descriptive statistic was performed to describe the soil properties and CCC. Then, Pearson correlation analysis was used to show correlations between soil properties. One-way ANOVA was used to examine the effects of landscape position and landscape type on soil properties and CCC, and the least significant difference method (LSD) was used to compare the mean values.

\subsubsection{Redundancy Analysis Method}

To find the most important environmental factors that affect the soil properties and CCC in the experimental area, redundancy analysis (RDA) was carried for a constrained ranking analysis based on the experimental data. A Monte Carlo permutation test was used to find the relative importance of each environmental factors in explaining changes in soil properties. Redundancy analysis is a direct gradient analysis technique. Through community ranking, the community sample plots (species) investigated in an area were arranged according to their similarity to analyze the relationships between various species and the environment and effectively evaluate the impact of environmental variables on species [24]. In this research, RDA was applied to find the relationship between species variables (soil properties and CCC) and environmental variables (landscape positions and landscape types, slope surface, gradient, and aspect).

It is worth noting that the gradient length should be measured by detrended correspondence analysis (DCA) on the sample before constraint analysis. Since the first gradient length was $0.6<3.0$, RDA is the most appropriate method [25]. Before RDA analysis, two data matrices (species data and environmental data) were built, and the environmental data were encoded. In this study, landscape types were divided into two types: 1 represents the sloping landscape and 2 the terraced landscape. Landscape position can be divided into FS, MS, and US, represented by 1,2 , and 3, respectively. The experimental slope surface was divided into the terraced field and sloping field, represented by 1 and 2, respectively. The actual measured values were used to represent the slope and aspect.

\section{Results and Discussion}

\subsection{The Description of Soil Properties and CCC}

Table 3 shows the statistical variables of soil properties and CCC under different landscape positions and landscape types. The content ranges of soil properties and CCC were as follows: CCC: $66.03-163.40$, total nitrogen: $0.55-2.70 \mathrm{~g} / \mathrm{kg}$, total phosphorus: 0.19-1.75 g/ kg, total potassium: $11.76-35.11 \mathrm{~g} / \mathrm{kg}$, available nitrogen: $30.60-185.50 \mathrm{mg} / \mathrm{kg}$, available phosphorus: $0.30-50.70 \mathrm{mg} / \mathrm{kg}$, available potassium: $50.50-273.40 \mathrm{mg} / \mathrm{kg}$, soil organic matter: $9.30-51.00 \mathrm{~g} / \mathrm{kg}$, and soil $\mathrm{pH}: 5.73-7.54$. The average content of soil properties followed a decreasing order: available potassium $>$ available nitrogen $>$ available phosphorus $>$ soil organic matter $>$ total potassium $>$ total nitrogen $>$ total phosphorus. The coefficient of variation (CV) of soil properties and CCC ranged from $27.60 \%$ to $83.82 \%$ (Table 3), showing medium variation $(10 \% \leq \mathrm{CV} \leq 100 \%)$, indicating that the soil properties and CCC varied greatly in different landscape positions and types. 
Table 3. Descriptive statistics for soil properties and the chlorophyll content of citrus (CCC).

\begin{tabular}{cccccccccc}
\hline Item & CCC & $\begin{array}{c}\text { TN } \\
(\mathbf{g} / \mathbf{k g})\end{array}$ & $\begin{array}{c}\text { TP } \\
(\mathbf{g} / \mathbf{k g})\end{array}$ & $\begin{array}{c}\text { TK } \\
(\mathbf{g} / \mathbf{k g})\end{array}$ & $\begin{array}{c}\mathbf{A N} \\
(\mathbf{m g} / \mathbf{k g})\end{array}$ & $\begin{array}{c}\text { AP } \\
(\mathbf{m g} / \mathbf{k g})\end{array}$ & $\begin{array}{c}\text { AK } \\
(\mathbf{m g} / \mathbf{k g})\end{array}$ & $\begin{array}{c}\text { SOM } \\
(\mathbf{g} / \mathbf{k g})\end{array}$ & $\mathbf{p H}$ \\
\hline Range & 97.37 & 2.15 & 1.56 & 23.35 & 154.90 & 50.40 & 222.90 & 41.70 & 1.81 \\
Minimum & 66.03 & 0.55 & 0.19 & 11.76 & 30.60 & 0.30 & 50.50 & 9.30 & 5.73 \\
Maximum & 163.40 & 2.70 & 1.75 & 35.11 & 185.50 & 50.70 & 273.40 & 51.00 & 7.54 \\
Mean & 119.59 & 1.30 & 0.77 & 16.45 & 76.39 & 16.83 & 157.25 & 21.40 & 6.81 \\
SD & 33.72 & 0.60 & 0.51 & 4.54 & 38.67 & 16.40 & 63.66 & 11.67 & 0.58 \\
CV (\%) & 28.20 & 46.15 & 66.23 & 27.60 & 50.62 & 61.40 & 40.48 & 54.53 & 83.82 \\
\hline
\end{tabular}

$\mathrm{SD}=$ standard deviation, $\mathrm{CV}=$ coefficient of variation, $\mathrm{TN}=$ total nitrogen, $\mathrm{TP}=$ total phosphorus, $\mathrm{TK}=$ total potassium, $\mathrm{AN}=$ available nitrogen, $\mathrm{AP}=$ available phosphorus, $\mathrm{AK}=$ available potassium, $\mathrm{SOM}=$ soil organic matter, $\mathrm{CCC}=$ chlorophyll content of citrus.

\subsection{Soil Properties Correlations}

A significant correlation was found between many soil properties measurements (Table 4). The content of total nitrogen (TN) was significantly positively correlated with total phosphorus (TP), available nitrogen (AN), available phosphorus (AP), available potassium (AK), and soil organic matter (SOM). SOM was significantly positively correlated with AN, $\mathrm{TP}, \mathrm{AP}(p<0.01)$, and AK $(p<0.05)$. The increasing SOM can promote the activity of soil enzymes, and promote the decomposition of plant and animal residues and humus, thus releasing nitrogen and potassium [26]. Moreover, SOM has a significant promoting effect on soil nutrient retention and nutrient supply capacity, which also suggests that the future fertilization should be based on organic fertilizer, supplemented by fertilizer, to maintain anthropogenic mellowing of soil, to meet the nutritional requirements of stable yield, high yield, and good quality of citrus. Soil $\mathrm{pH}$ was negatively correlated with $\mathrm{TN}, \mathrm{AN}, \mathrm{AK}$, and SOM, and it was an important index reflecting soil parent material properties and weathering and leaching conditions [27].

Table 4. Pearson correlation coefficients between soil properties.

\begin{tabular}{|c|c|c|c|c|c|c|c|}
\hline & $\mathbf{T N}$ & TP & TK & AN & $\mathbf{A P}$ & AK & SOM \\
\hline $\mathrm{TP}$ & $0.687 * *$ & & & & & & \\
\hline TK & -0.058 & 0.096 & & & & & \\
\hline $\mathrm{AN}$ & $0.930 * *$ & $0.584^{* *}$ & -0.075 & & & & \\
\hline $\mathrm{AP}$ & $0.744^{* *}$ & $0.876^{* *}$ & 0.089 & $0.737^{* *}$ & & & \\
\hline $\mathrm{AK}$ & $0.607 * *$ & $0.458 *$ & -0.094 & $0.660 * *$ & $0.653^{* *}$ & & \\
\hline SOM & $0.954^{* *}$ & $0.699 * *$ & -0.120 & $0.876^{* *}$ & $0.744^{* *}$ & $0.475^{*}$ & \\
\hline $\mathrm{pH}$ & $-0.537^{* *}$ & -0.297 & 0.089 & $-0.582 * *$ & 0.539 * & $-0.611^{* *}$ & -0.420 * \\
\hline
\end{tabular}

\subsection{The Effect of Landscape Positions on Soil Properties and CCC}

Most soil properties and CCC were significantly different in landscape positions (Table 5). The results of multiple comparisons showed that the CCC among the three landscape positions showed the order of MS $>$ US > FS, and the CCC at the FS was significantly different from the US and MS ( $p \leq 0.001$, Figure 2). Vladimir et al. [28] showed that under the same photosynthetic photon flux density, the fluorescence intensity excited by blue light is 2.5 to 3 times that of red light. Blue light significantly promoted the formation and accumulation of chlorophyll $[29,30]$. In the mountainous environment, the landscape position directly affects the illumination conditions, and the solar radiation at the FS is lower than the MS and US. Therefore, the CCC at the US and MS is extremely significantly higher than that the FS. At the same time, sunlight may also affect the formation of local microclimates, and differences in microclimates can affect the distribution of plant communities, which in turn affects the growth and development of citrus trees [31]. Additionally, a study by Qiang Fu et al. [32,33] showed that in the soil at a depth of $0-20 \mathrm{~cm}$, the higher the landscape position, the greater the soil moisture content, and chlorophyll content is positively related to soil moisture. Therefore, the significant differences of CCC in landscape positions may be caused by many reasons. 


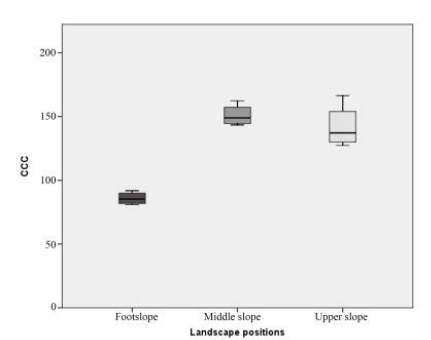

(a)

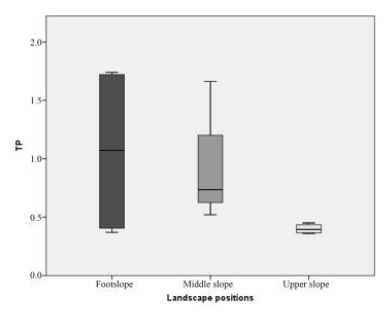

(c)

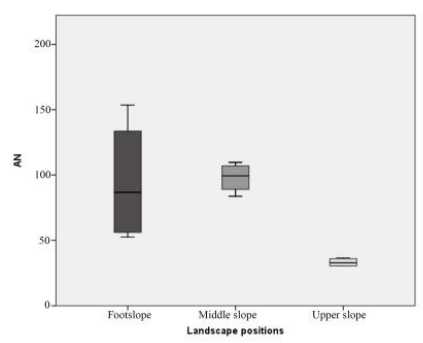

(e)

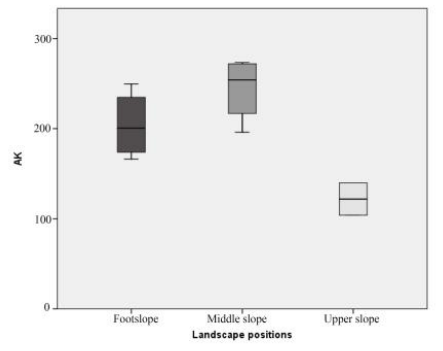

(g)

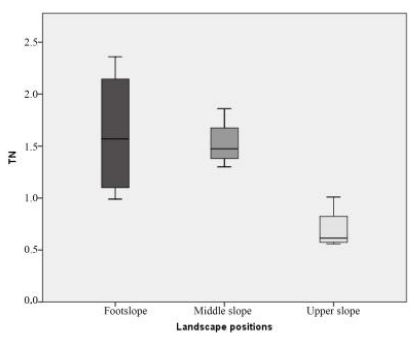

(b)

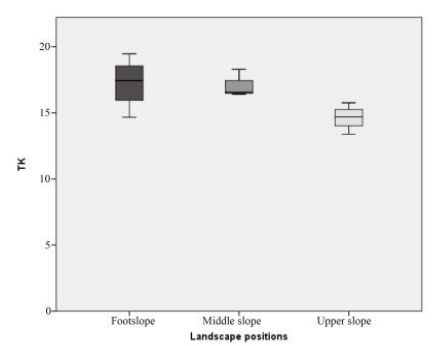

(d)

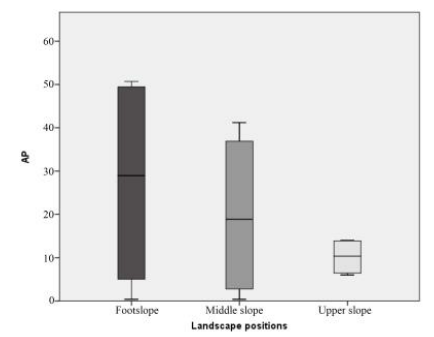

(f)

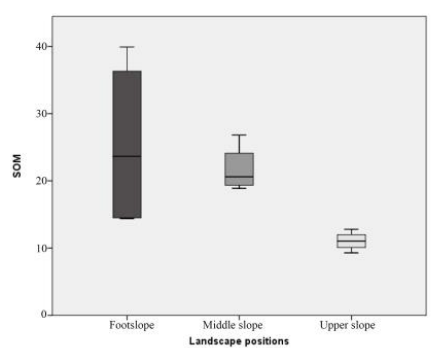

(h)

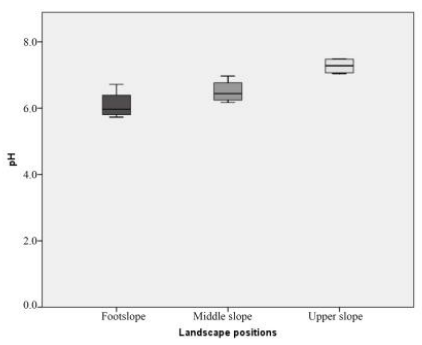

(i)

Figure 2. Variations of soil properties and CCC in different landscape positions. (a) Changes of citrus chlorophyll content; (b) Changes of total nitrogen content; (c) Changes of total phosphorus content; (d) Changes of total potassium content; (e) Changes of available nitrogen content; (f) Changes of available phosphorus content; (g) Changes of available potassium content; (h) Changes of soil organic matter content; (i) Changes of $\mathrm{pH}$. 
Table 5. Mean comparisons of soil properties by landscape positions of the study site.

\begin{tabular}{|c|c|c|c|c|c|c|c|c|c|}
\hline \multirow[b]{2}{*}{ LS } & \multirow[b]{2}{*}{$\mathrm{CCC}$} & \multicolumn{7}{|c|}{ Soil Properties } & \multirow[b]{2}{*}{ PH } \\
\hline & & $\begin{array}{c}\mathrm{TN} \\
(\mathrm{g} / \mathrm{kg})\end{array}$ & $\begin{array}{c}\text { TP } \\
\text { (g/kg) }\end{array}$ & $\begin{array}{c}\text { TK } \\
(\mathrm{g} / \mathrm{kg})\end{array}$ & $\begin{array}{c}\mathrm{AN} \\
(\mathrm{mg} / \mathrm{kg})\end{array}$ & $\begin{array}{c}\mathrm{AP} \\
(\mathrm{mg} / \mathrm{kg})\end{array}$ & $\begin{array}{c}\text { AK } \\
(\mathrm{mg} / \mathrm{kg})\end{array}$ & $\begin{array}{l}\text { SOM } \\
(\mathrm{g} / \mathrm{kg})\end{array}$ & \\
\hline FS & 85.80 & 1.62 & 1.06 & 17.25 & 94.93 & 27.25 & 204.30 & 25.40 & 6.10 \\
\hline MS & 150.88 & 1.53 & 0.91 & 16.96 & 98.08 & 19.85 & 244.40 & 21.73 & 6.51 \\
\hline US & 141.96 & 0.70 & 0.40 & 14.64 & 33.25 & 10.18 & 121.85 & 11.05 & 7.27 \\
\hline $\mathrm{F}$ & $37.57 * * *$ & $6.15^{*}$ & 1.73 & $4.36^{*}$ & $6.64 *$ & 0.80 & $14.90^{* *}$ & 3.67 & $11.53^{* *}$ \\
\hline
\end{tabular}

The soil $\mathrm{pH}$ value is extremely significantly correlated with the landscape position $(p<0.01)$, manifested as a decrease along the downslope. Due to the citrus orchard being located on the slope of the Three Gorges Reservoir area, the topography has an impact on soil nutrient loss. The leaching or loss of base ions, especially calcium ions, makes the soil acidified [34]. On the contrary, the TN and TK accumulate along the downslope. The multiple comparison results showed that the contents of total nitrogen and total potassium were the lowest in the US position and tended to be the highest at FS position. The content in the US is significantly lower than the FS $(p<0.05)$. This result is consistent with the research conclusion of Hu Chenxia et al. and may be due to the nutrient deposition in the US and the production and residue of plants [35]. The contents of AN and AK were the highest content in the MS, and significantly higher than those in the US $(p<0.05, p<0.01$, respectively). It could be due to better temperature and moisture in the MS than in the US, or better light conditions than at the FS [36]. Although the difference of TP, AP, and SOM among landscape positions was not significant $(p>0.05)$, they generally tended to accumulate along the downslope, which was consistent with the fact that TN, AN, TK, and AK had lower values on the US and higher values at the FS. Zhang Jianhui et al. [37] showed that the main erosion process in a medium-long slope $(40-110 \mathrm{~m})$ was water erosion, and soil nutrients were carried from the upper slope to the foot slope by surface runoff, leading to a decrease in soil quality in the US position.

In general, most soil properties and CCC in orchards have significant correlations among landscape positions. Specifically, most soil properties show a higher value in the MS and FS and lower in the US [38]. The lowest levels of other soil properties, such as soil organic carbon, were also usually found in the US position [39]. The soil properties of the US were worse than those of the MS and FS position. However, unsustainable land use in the upper landscape position has an impact on the lower slope area. The soil nutrient loss is the main reason for the decline of soil quality and non-point source pollution. Therefore, the balance and improvement of soil quality is the critical factor to achieve sustainable agricultural development [40-42]. Xue Zhijing et al. [43] suggested that the high vegetation cover can reduce runoff and soil loss, and then maintain soil nutrients better. Additionally, the effects of tillage erosion cannot be ignored. One solution is to reduce tillage on uphill sites. The other solution is more appropriate to this area to improve the soil fertility by intercropping and applying green manure or organic manure in the US. Applying biological organic fertilizer instead of chemical fertilizer can reduce the emission of nitrogen dioxide and thus improve the acidification and eutrophication of surface water [44]. Therefore, the effects of landscape positions on soil properties and CCC should be further studied.

\subsection{The Effect of Landscape Types on Soil Properties and CCC}

Some soil properties of different landscape types in the same landscape position (US) in the orchard were significantly different (Table 6). The mean value of TN and TK ranged from $0.70-1.08 \mathrm{~g} / \mathrm{kg}$ and $14.64-17.68 \mathrm{~g} / \mathrm{kg}$, respectively. Multiple comparison results showed that the TN and TK contents in terraced fields were significantly higher than in sloping fields $(p<0.05)$. The contents of AN, AP, and other nutrients that could be directly absorbed by crops in terraced fields were significantly higher than those in sloping $(p \leq 0.001)$, and the contents of AN and AP in terraced fields were $77.08 \%$ and 
$217.58 \%$ higher than those in sloping, respectively. Although there was no significant difference in TP, AK, SOM, and $\mathrm{pH}$ among different landscape types $(p<0.05)$, further observation showed that their contents in terraced fields were still higher than those in sloping, indicating that the difference of landscape types did lead to the changes of soil properties.

The research conclusion is consistent with Fu Bojie et al. [45]. The soil properties of sloping land being lower than terraces may be the combined action of water erosion and tillage erosion. $\mathrm{Xu}$ Chang et al. $[46,47]$ showed that rainfall and surface runoff were the impetus of soil nutrient loss. Compared with the sloping field, the slope length and angle of the terraced orchard were significantly reduced, which resulted in the reduction of soil erosion caused by the topography and the better preservation of soil nutrients. At the same time, it reduces water body pollution caused by soil particles, nitrogen, phosphorus, and other elements in farmland under the scouring effect of rainwater and runoff. Furthermore, effects of contour tillage on soil movement (translocation and erosion) were examined by Zhang Jianhui et al. in the steep hillslopes of the Sichuan basin using a physical tracer method. The results showed that tillage significantly affects soil migration on sloping land. The tillage erosion rate under contour tillage was $77 \%$ lower than that under downslope tillage [48]. In the future farming of sloping, especially at the top and upper slopes with high soil property variability, it is necessary to consider the cultivation method of contour terraced fields, which is conducive to soil conservation and has a charming farmland landscape [49]. Bo Sun et al. [50,51] indicated that excessive application of nitrogen fertilizer and pesticides is considered to cause water pollution in the Yangtze River basin. The solution is to reduce the loss of soil nutrients and maintain a good farmland ecosystem. Therefore, compared with slope land, terrace farming with good ecological, landscape, and economic benefits is a more suitable farming method for farmland in the Yangtze River Basin. At that time, the charming terraced orchard and the beautiful Yangtze River will become a brilliant and unique scene, which will make the leisure and sightseeing agriculture in this region develop better. Moreover, Shimbahri et al. [52] conducted a study on the effect of terraces on soil water content in an arid area of Ethiopia. The results showed that terraces do have good performance in soil and water conservation. Thus, we should also pay attention to the impact of landscape types on soil water content in future research, which is very important for arid and semi-arid regions in the world.

Table 6. Mean comparisons of soil properties by landscape types.

\begin{tabular}{|c|c|c|c|c|c|c|c|c|c|}
\hline \multirow[b]{2}{*}{ LT } & \multirow[b]{2}{*}{$\mathrm{CCC}$} & \multicolumn{7}{|c|}{ Soil Properties } & \multirow[b]{2}{*}{ PH } \\
\hline & & $\begin{array}{c}\text { TN } \\
(\mathrm{g} / \mathrm{kg})\end{array}$ & $\begin{array}{c}\mathrm{TP} \\
(\mathrm{g} / \mathrm{kg})\end{array}$ & $\underset{(\mathrm{g} / \mathrm{kg})}{\mathrm{TK}}$ & $\underset{(\mathrm{mg} / \mathrm{kg})}{\mathrm{AN}}$ & $\begin{array}{c}\mathrm{AP} \\
(\mathrm{mg} / \mathrm{kg})\end{array}$ & $\begin{array}{c}\mathrm{AK} \\
(\mathrm{mg} / \mathrm{kg})\end{array}$ & $\begin{array}{l}\text { SOM } \\
(\mathrm{g} / \mathrm{kg})\end{array}$ & \\
\hline Slope & 141.96 & 0.70 & 0.40 & 14.64 & 33.25 & 10.18 & 121.85 & 11.05 & 7.27 \\
\hline Terrace & 139.83 & 1.08 & 0.99 & 17.68 & 58.88 & 32.33 & 127.05 & 19.28 & 7.49 \\
\hline F value & 0.05 & $6.43 *$ & 10.41 & 7.17 * & $30.69 * * *$ & $45.22 * * *$ & 0.10 & 3.97 & 3.02 \\
\hline
\end{tabular}

\subsection{Redundancy Analysis (RDA)}

Through redundancy analysis, we obtained the relationship among soil properties and CCC and environmental variables. The significance of the constraint ordination was tested by the Monte Carlo permutation test (499 permutations were performed). The results showed that the tests on the first and second constraint axes were obvious $(p=0.028$ and 0.002 , respectively). The first and second constraint axes together explain $81.32 \%$ of the relationship between the species variables and environmental variables. Therefore, we chose the first two constraint axes with high and significant eigenvalues to draw a biplot for observation and then tried to explain it.

The RDA ordination diagram is explained below: environmental variables (explanatory variables) in red arrows indicate species variables (response variables) with blue. The angle between the arrow of the environmental variables and response variables reflects 
the correlation (but not the meaning of the angle between the response variable): when the angle is acute, the correlation is positive; correlation is negative when the angle is greater than 90 degrees. The length of the line between the red arrow (environmental variables) and the origin is directly proportional to the degree of correlation between an environmental factor and the distribution of community and species. The angle between the arrow of the environmental variable and the constraint axis represents correlation. The smaller the angle is, the greater the correlation will be. If it is orthogonal, it will be irrelevant. The blue arrow (species variable) points from the origin to the corresponding coordinate of the species score. The direction the arrow points to indicates the direction in which the abundance of the species has increased. The correlation between species and environmental variables was displayed by a perpendicular projection of the species arrow-tips onto the line overlaying the environmental arrow. The longer the projection, the higher the correlation.

The results of the RDA ordination diagram (Figure 3) show that Axis1 is positively correlated with slope gradient and aspect. The first constraint axis is mainly interpreted as slope gradient and aspect because of the length of the arrow. The second ordination axis (Axis2) has a great negative correlation with landscape position. Therefore, the second ordination axis is mainly interpreted as landscape position. The CCC is highly correlated with landscape position, followed by slope gradient, and negatively with aspect. The highest negative correlation with landscape positions is TN, followed by TK, AN, SOM, and TP. Although most soil properties are significantly affected by landscape positions, the influence of slope and aspect cannot be ignored.

In the RDA ordination diagram, slope gradient and aspect are the main determinants of Axis 1 (Figure 3). TN, TP, AN, AK, and SOM are positively correlated with slope gradient and negatively with aspect, which is in keeping with the research conclusions of Holden et al. [53]. Although the heterogeneity of soil properties is influenced by many factors, such as climate, soil parent material, and biology, many soil properties changes can be attributed to topography [54]. The movement and accumulation of soil solutions are significantly affected by slope gradient and aspect, leading to spatial differences in soil properties [55].

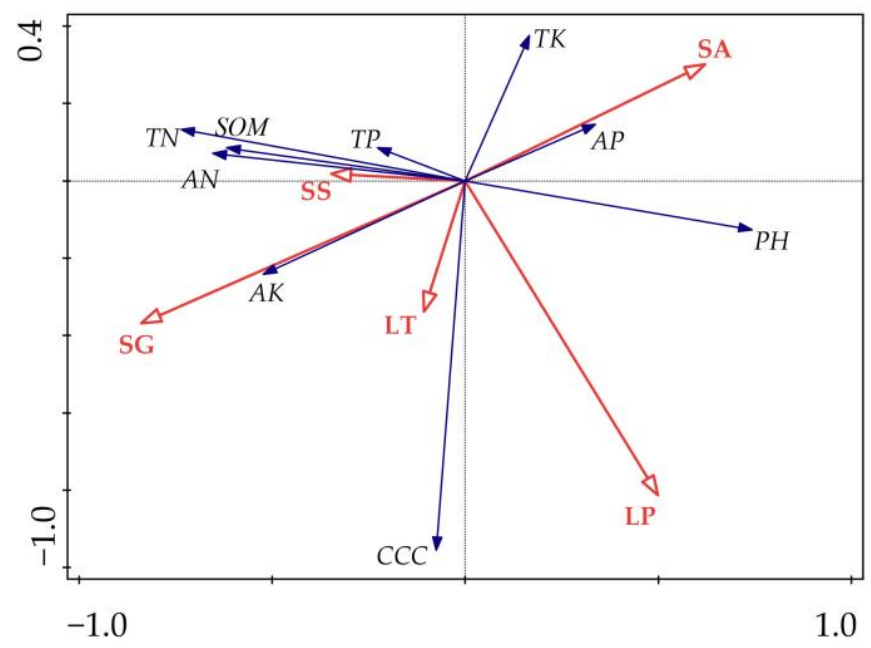

Figure 3. Ordination biplot of redundancy analysis (RDA) displaying the effects of the selected environmental variables on soil properties and CCC. LT = landscape type, LP = landscape position, SG = slope gradient, $\mathrm{SA}=$ slope aspect, $\mathrm{SS}=$ slope surface, $\mathrm{CCC}=$ chlorophyll content of citrus.

The correlation between CCC and slope gradient and aspect may be related to solar radiation. The slope aspect, a topographic factor that changes regional microclimate, determines the solar radiation amount received by the slope surface [56]. Smith's [57] research shows that many environmental changes are related to solar radiation. Sun Ying et al. 
showed that the chlorophyll content in plants also had a relationship with light intensity $[58,59]$. Therefore, in this study, with the change of slope gradient and aspect, the amount of solar radiation probably changes accordingly, which could lead to the CCC changes.

\section{Conclusions}

In conclusion, our study clearly shows significant changes in soil properties and CCC among different landscape positions and landscape types in the Three Gorges Reservoir Area. Most soil properties showed the highest content in the footslope and terraced landscape and the lowest in the upper slope and sloping. The CCC in the footslope was significantly less than in the MS and US location. In addition to the strong effect of landscape, the well-known principle that spatial heterogeneity of soil properties is affected by topographic factors such as slope gradient and aspect was also confirmed in this research. These results indicated that the changes of soil properties and CCC in this area were mainly affected by landscape position, landscape type, and topography. For Fengjie County to develop suburban modern agriculture and sightseeing agriculture, determining the targeted land management measures of orchards to change the farmland landscape and orchard planting layout is more in line with the requirements of regional development [60]. It can not only improve the soil quality and yield of orchards and reduce the unnecessary nutrient waste and non-point source pollution caused by orchards, but also provide ideas for the landscape design of orchards to realize the sustainable development of agriculture and ecology in this area.

It is necessary to carry out similar and larger scale research in other catchments such as the Yellow River basin or citrus planting areas such as Southern Jiangxi, China to determine the complex influence law between soil-landscape-crop under different soil parent materials, climate, geographical conditions, etc., and formulate the applicable regional eco-agricultural transformation scheme. In addition, this study has the same reference value for the development of sustainable agriculture in other tropical and subtropical countries such as India and Nigeria. However, our research method has some limitations, such as the research on the spatial distribution of soil properties being weak. Therefore, we summarized several lessons for future researchers to conduct further study. 1. More soil physical properties, such as soil bulk density, aeration, permeability, and adhesion, can be included in soil analysis. 2. More response variables can be included in leaf analysis, such as chlorophyll a, chlorophyll b, carotenoids, leaf area, specific leaf index, etc.

Author Contributions: Conceptualization and methodology, G.Z. and S.S. (Siyue Sun); software, validation, investigation and formal analysis, S.S. (Siyue Sun) and S.S. (Shufang Song); resources and data curation, T.H.; writing-original draft preparation, S.S. (Siyue Sun); writing-review and editing, and supervision, G.Z. and X.C.; visualization, S.S. (Siyue Sun); project administration, X.C.; funding acquisition, T.H., G.Z., and S.S. (Shufang Song). All authors have read and agreed to the published version of the manuscript.

Funding: This research was funded by the National Natural Science Foundation of China, grant number: 51808215, Advantage Research Team Project of Guangxi Academy of Agricultural Sciences, grant number: 2021YT037, and Basic Ability Improvement Project for Young and Middle-aged Teachers in Guangxi Universities and Research and Development Fund for Young Teachers in Guangxi University of Finance and Economics of China, grant numbers: 2018KY0505, 2018QNB10.

Acknowledgments: We sincerely thank Fengjie County Agricultural Development Ecology Co., Ltd. for providing us with experimental base and some help. We are also grateful to the journal editors and anonymous reviewers for their constructive comments.

Conflicts of Interest: The authors declare no conflict of interest.

\section{References}

1. Wen, Z.F. Thoughts on the Construction of Chongqing Citrus Industry Development Technology System. Southwest Hortic. 2002, $30,15-17+20$. 
2. Liu, Y.S.; Zhang, Z.W.; Wang, J.Y. Regional differentiation and comprehensive regionalization scheme of modern agriculture in China. Acta Geogr. Sin. 2018, 73, 203-218.

3. Zhang, X.; Zhang, J.; Li, L.; Zhang, Y.; Yang, G. Monitoring Citrus Soil Moisture and Nutrients Using an IoT Based System. Sensors 2017, 17, 447. [CrossRef] [PubMed]

4. Abdollahnejad, A.; Panagiotidis, D.; Shataee Joybari, S.; Surový, P. Prediction of Dominant Forest Tree Species Using QuickBird and Environmental Data. Forests 2017, 8, 42. [CrossRef]

5. Wan, S.-Z.; Gu, H.-J.; Yang, Q.-P.; Hu, X.-F.; Fang, X.-M.; Singh, A.N.; Chen, F.-S. Long-term fertilization increases soil nutrient accumulations but decreases biological activity in navel orange orchards of subtropical China. J. Soils Sediments 2017, 17, 2346-2356. [CrossRef]

6. Jiang, P.; Thelen, K.D. Effect of soil and topographic properties on crop yield in a north-central corn-soybean cropping system. Agron. J. 2004, 96, 252-258. [CrossRef]

7. Kravchenko, A.N.; Bullock, D.G. Correlation of corn and soybean grain yield with topography and soil properties. Agron. J. 2000, 92, 75-83. [CrossRef]

8. Jiang, Y.; Sun, K.; Guo, X.; Ye, Y.; Rao, L.; Li, W. Prediction of spatial distribution of soil properties based on environmental factors and neighbor information. Res. Environ. Sci. 2017, 30, 1059-1068.

9. XiaoHua, X.; Xin-Fa, X.; Sheng, L.; ShaSha, F.; Gaowei, W. Soil Erosion Environmental Analysis of the Three Gorges Reservoir AreaBased on the "3S" Technology. Procedia Environ. Sci. 2011, 10, 2218-2225. [CrossRef]

10. Teng, M.; Zeng, L.; Xiao, W.; Huang, Z.; Zhou, Z.; Yan, Z.; Wang, P. Spatial variability of soil organic carbon in Three Gorges Reservoir area, China. Sci. Total Environ. 2017, 599, 1308-1316. [CrossRef] [PubMed]

11. Shen, Z.; Chen, L.; Hong, Q.; Qiu, J.; Xie, H.; Liu, R. Assessment of nitrogen and phosphorus loads and causal factors from different land use and soil types in the Three Gorges Reservoir Area. Sci. Total Environ. 2013, 454, 383-392. [CrossRef]

12. Xu, F.; Cai, Q.G.; Wu, S.A.; Zhang, G.Y.; Ding, S.W.; Cai, C.F. Research on the Control of Soil Nutrient Loss by Slope Land Ecological Engineering in the Three Gorges Reservoir Area-Take contour hedges as an example. Geogr. Res. 2000, 19, 303-310.

13. Hook, P.B.; Burke, I.C. Biogeochemistry in A Shortgrass Landscape: Control by Topography, Soil Texture, and Microclimate. Ecology 2000, 81, 2686-2703. [CrossRef]

14. Ovalles, F.A.; Collins, M.E. Soil-landscape Relationships and Soil Variability in North Central Florida. Soil Sci. Soc. Am. J. 1986, 50, 401-408. [CrossRef]

15. Arnaez, J.; Lasanta, T.; Errea, M.P.; Ortigosa, L. Land abandonment, landscape evolution, and soil erosion in a Spanish Mediterranean mountain region: The case of Camero Viejo. Land Degrad. Dev. 2011, 22, 537-550. [CrossRef]

16. Wang, J.; Fu, B.; Qiu, Y.; Chen, L. Soil nutrients in relation to land use and landscape position in the semi-arid small catchment on the loess plateau in China. J. Arid Environ. 2001, 48, 537-550. [CrossRef]

17. Park, S.J.; Vlek, P.L.G. Environmental correlation of three-dimensional soil spatial variability: A comparison of three adaptive techniques. Geoderma 2002, 109, 117-140. [CrossRef]

18. Gogoi, M.; Basumatary, M. Estimation of the chlorophyll concentration in seven Citrus species of Kokrajhar district, BTAD, Assam, India. Trop. Plant Res. 2018, 5, 83-87. [CrossRef]

19. Shaahan, M.M.; El-Sayed, A.A.; Abou El-Nour, E.A.A. Predicting nitrogen, magnesium and iron nutritional status in some perennial crops using a portable chlorophyll meter. Sci. Hortic. 1999, 82, 339-348. [CrossRef]

20. Haboudane, D.; Miller, J.R.; Tremblay, N.; Zarco-Tejada, P.J.; Dextraze, L. Integrated narrow-band vegetation indices for prediction of crop chlorophyll content for application to precision agriculture. Remote Sens. Environ. 2002, 81, 416-426. [CrossRef]

21. Shi, D.-Y.; Liu, Z.-X.; Jin, W.-W. Biosynthesis, catabolism and related signal regulations of plant chlorophyll. Hereditas 2009, 31, 698-704. [CrossRef]

22. Esposti, M.D.D.; de Siqueira, D.L.; Pereira, P.R.G.; Venegas, V.H.A.; Salomão, L.C.C.; Filho, J.A.M. Assessment of Nitrogenized Nutrition of Citrus Rootstocks Using Chlorophyll Concentrations in the Leaf. J. Plant Nutr. 2003, 26, 1287-1299. [CrossRef]

23. Brubaker, S.C.; Jones, A.J.; Lewis, D.T.; Frank, K. Soil Properties Associated with Landscape Position. Soil Sci. Soc. Am. J. 1993, 57, 235-239. [CrossRef]

24. Tong, L.L. Application of RDA analysis in Canoco4.5 in water ecological evaluation. Technol. Wind 2018, 2, 47.

25. Zhai, J.; Song, Y.; Entemake, W.; Xu, H.; Wu, Y.; Qu, Q.; Xue, S. Change in Soil Particle Size Distribution and Erodibility with Latitude and Vegetation Restoration Chronosequence on the Loess Plateau, China. Int. J. Environ. Res. Public Health 2020, 17, 822. [CrossRef]

26. Liu, Y.; He, N.; Wen, X.; Yu, G.; Gao, Y.; Jia, Y. Patterns and regulating mechanisms of soil nitrogen mineralization and temperature sensitivity in Chinese terrestrial ecosystems. Agric. Ecosyst. Environ. 2016, 215, 40-46. [CrossRef]

27. Weng, H.L.; Ci, E.; Li, S.; Lian, M.S.; Chen, L. Pedogenetic Process and Taxonomy of Yellow Soil in Chongqing, China. Acta Pedol. Sin. 2020, 57, 579-589.

28. Lysenko, V.; Kosolapov, A.; Usova, E.; Tatosyan, M.; Varduny, T.; Dmitriev, P.; Rajput, V.; Krasnov, V.; Kunitsina, A. Chlorophyll fluorescence kinetics and oxygen evolution in Chlorella vulgaris cells: Blue vs. red light. J. Plant Physiol. 2021, 258-259, 153392. [CrossRef]

29. Chen, H.; Li, Q.-P.; Zeng, Y.-L.; Deng, F.; Ren, W.-J. Effect of different shading materials on grain yield and quality of rice. Sci. Rep. 2019, 9, 9992. [CrossRef] 
30. Richter, G.; Wessel, K. Red light inhibits blue light-induced chloroplast development in cultured plant cells at the mRNA level. Plant Mol. Biol. 1985, 5, 175-182. [CrossRef]

31. Sigua, G.C.; Coleman, S.W. Spatial distribution of soil carbon in pastures with cow-calf operation: Effects of slope aspect and slope position. J. Soils Sediments 2010, 10, 240-247. [CrossRef]

32. Guo, X.; Fu, Q.; Hang, Y.; Lu, H.; Gao, F.; Si, J. Spatial Variability of Soil Moisture in Relation to Land Use Types and Topographic Features on Hillslopes in the Black Soil (Mollisols) Area of Northeast China. Sustainability 2020, 12, 3552. [CrossRef]

33. Jia, D.; Qian, W.; Hui, Y.; Shouren, Z. Effects of topographic variations and soil characteristics on plant functional traits in a subtropical evergreen broad-leaved forest. Biodivers. Sci. 2011, 19, 158-167. [CrossRef]

34. Tang, X.F.; Wang, Y.Q.; Wang, Y.J.; Guo, P.; Hu, B.; Sun, S.Q. Influence of hydrological processes on the runoff variation of base cations in Jinyun Mountain. Acta Ecol. Sin. 2014, 34, 7047-7056.

35. Hu, C.; Wright, A.L.; Lian, G. Estimating the spatial distribution of soil properties using environmental variables at a catchment scale in the loess hilly area, China. Int. J. Environ. Res. Public Health. 2019, 16, 491. [CrossRef]

36. Ni, S.J.; Zhang, J.H. Variation of chemical properties as affected by soil erosion on hillslopes and terraces. Eur. J. Soil Sci. 2007, 58, 1285-1292. [CrossRef]

37. Su, Z.A.; Zhang, J.H.; Nie, X.J. Effect of Soil Erosion on Soil Properties and Crop Yields on Slopes in the Sichuan Basin, China. Pedosphere 2010, 20, 736-746. [CrossRef]

38. Clemens, G.; Fiedler, S.; Nguyen, D.C.; Nyuyen, V.D.; Schuler, U.; Stahr, K. Soil fertility affected by land use history, relief position, and parent material under a tropical climate in NW-Vietnam. Catena 2010, 81, 87-96. [CrossRef]

39. Hao, Y.; Lal, R.; Owens, L.B.; Izaurralde, R.C.; Post, W.M.; Hothem, D.L. Effect of cropland management and slope position on soil organic carbon pool at the North Appalachian Experimental Watersheds. Soil Tillage Res. 2002, 68, 133-142. [CrossRef]

40. Ao, C.; Yang, P.; Ren, S.; Xing, W. Mathematical model of ammonium nitrogen transport with overland flow on a slope after polyacrylamide application. Sci. Rep. 2018, 8, 6380. [CrossRef]

41. Doni, F.; Isahak, A.; Che Mohd Zain, C.R.; Wan Yusoff, W.M. Physiological and growth response of rice plants (Oryza sativa L.) to Trichoderma spp. inoculants. AMB Express 2014, 4, 45. [CrossRef]

42. Naseem, F.; Zhi, Y.; Farrukh, M.A.; Hussain, F.; Yin, Z. Mesoporous ZnAl2Si10O24 nanofertilizers enable high yield of Oryza sativa L. Sci. Rep. 2020, 10, 10841. [CrossRef]

43. Xue, Z.; Cheng, M.; An, S. Soil nitrogen distributions for different land uses and landscape positions in a small watershed on Loess Plateau, China. Ecol. Eng. 2013, 60, 204-213. [CrossRef]

44. Lin, W.; Ding, J.; Xu, C.; Zheng, Q.; Zhuang, S.; Mao, L.; Li, Q.; Liu, X.; Li, Y. Evaluation of N2O sources after fertilizers application in vegetable soil by dual isotopocule plots approach. Ecol. Eng. 2020, 188, 109818.

45. Wang, J.; Fu, B.-j.; Qiu, Y.; Chen, L.-d. The effects of land use and its patterns on soil properties in a small catchment of the Loess Plateau. J. Environ. Sci. 2003, 15, 263-266.

46. Xu, C.; Xie, D.T.; Gao, M.; Tao, C.; Yu, L. Study on the Nitrogen and Phosphorus Loss Characteristics from Sloping Uplands in Small Watershed of Three Gorges Reservoir Region. J. Soil Water Conservation. 2011, 25, 1-5+10.

47. Shigaki, F.; Sharpley, A.; Prochnow, L.I. Rainfall intensity and phosphorus source effects on phosphorus transport in surface runoff from soil trays. Sci. Total Environ. 2007, 373, 334-343. [CrossRef] [PubMed]

48. Zhang, J. Assessment of tillage translocation and tillage erosion by hoeing on the steep land in hilly areas of Sichuan, China. Soil Tillage Res. 2004, 75, 99-107. [CrossRef]

49. Papiernik, S.K.; Lindstrom, M.J.; Schumacher, T.E.; Schumacher, J.A.; Malo, D.D.; Lobb, D.A. Characterization of soil profiles in a landscape affected by long-term tillage. Soil Tillage Res. 2007, 93, 335-345. [CrossRef]

50. Sun, B.; Zhang, L.; Yang, L.; Zhang, F.; Norse, D.; Zhu, Z. Agricultural Non-Point Source Pollution in China: Causes Mitigation Measures. AMBIO 2012, 41, 370-379. [CrossRef]

51. Ding, X.; Liu, L. Long-Term Effects of Anthropogenic Factors on Nonpoint Source Pollution in the Upper Reaches of the Yangtze River. Sustainability 2019, 11, 2246. [CrossRef]

52. Mesfin, G.S.; Almeida, O.; Yazew, E.; Bresci, E.; Castelli, G. Spatial Variability of Soil Moisture in Newly Implemented Agricultural Bench Terraces in the Ethiopian Plateau. Water 2019, 11, 2134. [CrossRef]

53. Moges, A.; Holden, N.M. Soil fertility in relation to slope position and agricultural land use: A case study of Umbulo catchment in southern Ethiopia. Environ. Manag. 2008, 42, 753-763. [CrossRef] [PubMed]

54. Gessler, P.; Chadwick, O.; Chamran, F.; Althouse, L.; Holmes, K. Modeling soil-landscape and ecosystem properties using terrain attributes. Soil Sci. Soc. Am. J. 2000, 64, 2046-2056. [CrossRef]

55. Tsui, C.-C.; Chen, Z.-S.; Hsieh, C.-F. Relationships between soil properties and slope position in a lowland rain forest of southern Taiwan. Geoderma 2004, 123, 131-142. [CrossRef]

56. Sigua, G.C.; Coleman, S.W.; Albano, J.; Williams, M. Spatial distribution of soil phosphorus and herbage mass in beef cattle pastures: Effects of slope aspect and slope position. Nutr. Cycl. Agroecosyst. 2011, 89, 59-70. [CrossRef]

57. Chin, G. Of Sunlight, Water, and Trees. Science 2005, 310, 19. [CrossRef]

58. Sun, Y.; Shi, J.A.; Shao, X.P.; Li, F.; Li, Q.; Gao, X.; Zhong, Q.; Zhao, W.Z. Effects of light intensity on photosynthetic pigment content and flowering of Jacaranda mimosifolia D. Don in different habitats. Chin. J. Appl. Environ. Biol. 2015, 21, 1150-1156. 
59. Yan, X.; Wang, D. Effects of shading on leaf characteristics and photosynthetic characteristics of Kuding tea tree. Acta Ecol. Sin. 2014, 34, 3538-3547. [CrossRef]

60. Wei, J.B.; Xiao, D.N.; Zeng, H.; Fu, Y.K. Spatial variability of soil properties in relation to land use and topography in a typical small watershed of the black soil region, northeastern China. Environ. Geol. 2008, 53, 1663-1672. [CrossRef] 